\title{
Research on the Application of Modern Educational Technology in College Physical Education
}

\author{
Xueqin Qin \\ Sichuan University of Arts and Science, Dazhou, China \\ 401642193@qq.com
}

\begin{abstract}
Keywords: College physical education; Modern educational technology; Application status; Strategy
\end{abstract}

\begin{abstract}
Objective: The purpose of the study is to show the application of modern educational technology in college physical education. Methods: the research methods adopted include literature, logical analysis and mathematical statistics. Results: Through the analysis of the current situation of PE teachers' cognition and application of modern educational technology, the application environment of modern educational technology in PE teaching, the evaluation of students' application of modern educational technology in PE teaching, the existing problems in the application of modern educational technology in PE teaching were analyzed. Conclusion: Physical education teachers should enhance the understanding of modern educational technology, colleges and universities should change the traditional knowledge of physical education, strengthen the investment in infrastructure, and give full play to the participation of students.
\end{abstract}

\section{Introduction}

Physical education in Colleges and universities is to cultivate students' certain physical training ability and sports skills, and help students form lifelong exercise habits. However, owing to the understanding of ideas and traditional teaching ideas, the "marginalization" of college physical education is more obvious, and the application of modern educational technology in college physical education is very little, even in some colleges and universities, there is almost no use of modern educational technology in physical education. Such a situation has seriously affected the effectiveness of physical education in Colleges and universities. In order to analyze the application of modern educational technology in college physical education, 86 teachers and 178 students in Sichuan province are investigated.

\section{Analysis of the Current Situation of PE Teachers' cognition and Application of Modern Educational Technology}

Physical Education teachers' cognition of Modern Educational Technology. According to the investigation of PE teachers'understanding of modern educational technology, the number of PE teachers who are familiar with modern educational technology is only 9 , accounting for $10 \%$. The survey shows that most teachers think that modern educational technology plays an important auxiliary role in physical education and is an important means to achieve physical education. There were 16 people who thought the impact was not obvious, accounting for 19\%. 5 people (about $6 \%$ ) believe that modern educational technology has no effect on physical education. From this result, most PE teachers believe that modern educational technology has a certain impact on PE teaching, but the effect is not very great.

The Application of Modern Educational Technology. Modern educational technology means mainly include network technology, computer multimedia technology, video technology, audio technology and so on. Survey shows that the use of network technology, video technology, audio technology is relatively high. In particular, network technology, 56 respondents $(64.93 \%)$ said that often used, occasionally used more than $31 \%$, almost no use of the proportion is very low, less than $4 \%$. 


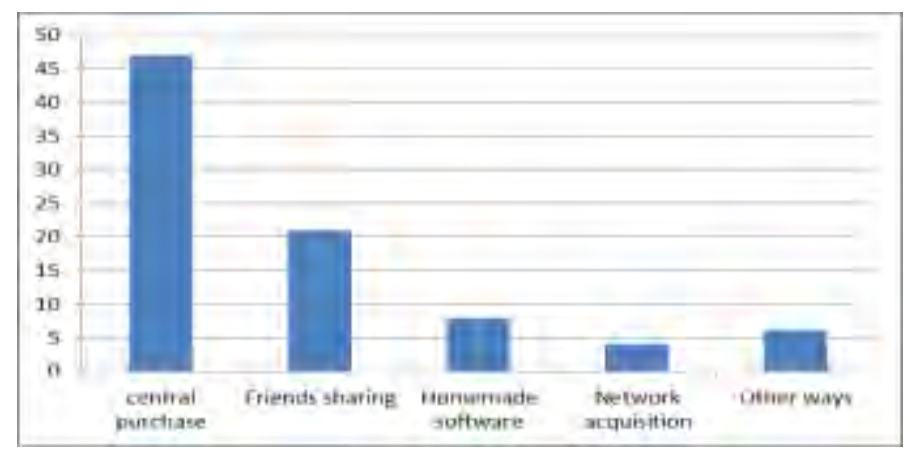

Figure 3. Source of teaching software

Source of Teaching Software. According to the survey, unified purchasing is the main channel for PE teachers' teaching software in Colleges and universities. A total of 47 teachers said they used unified purchasing teaching software from schools (or colleges, departments). In addition, 21 teachers obtained assistant teaching software from colleagues (friends). As for homemade software and slave network software, only eight teachers and four teachers surveyed said they would use them frequently. As for other channels, there are 6 teachers. Overall, the teachers interviewed relied too much on unified ordering for the source of teaching software, but less on other channels. This situation, on the one hand, is that the major universities (or departments) in order to unify the teaching, the teaching software for the unified procurement, thus affecting college PE teachers from other channels to obtain teaching software.

\section{The environment of modern educational technology application in Physical Education}

Funding Input. Funding is the core of ensuring the effectiveness of modern educational technology. In particular, modern educational technology is very demanding for all kinds of hardware equipment, and it also needs a certain amount of investment. The investigation shows that the shortage of funds is a prominent problem in the application of modern sports education technology in Colleges and universities. Among the 86 teachers, only 14 teachers were considered to be well funded, accounting for $16 \%$. There are 39 teachers who invest in general accounting, accounting for $45 \%$. There are 33 teachers who are not adequately funded, accounting for 38\%. Physical education teachers reflect that the use of modern educational technology in physical education is insufficient or general, which in fact reflects the predicament of "marginalization" of physical education in most colleges and universities. Due to the "Marginalization" of sports, less investment is devoted to modern educational technology.

Construction of Equipment. The application of modern educational technology depends on multimedia classrooms, networks and other equipment. From the results of the questionnaire, the interviewed teachers have a higher evaluation of network construction, but the evaluation of multimedia classroom construction is poor. There are 55 teachers who think network construction is good, but only 12 teachers who think multimedia classroom construction is good. The reason why teachers have a high evaluation of network construction is that under the background of the information age, universities have strengthened the network construction. However, in many colleges and universities, the multi-media classroom is hardly open to physical education, and still adheres to the traditional "physical education is extracurricular teaching" teaching ideas, so the evaluation of the multi-media classroom is poor.

\section{Problems in the Application of Modern Educational Technology in Physical Education Teaching}

Schools do not Attach much Importance. The application of modern educational technology in college physical education is inseparable from the support of colleges and universities. Whether modern educational technology can achieve the desired results in physical education teaching 
depends on the support of the school. However, from the results of the questionnaire, many PE teachers generally reflect that schools in modern educational technology attention and support is not high. Overall, the current major colleges and universities on the use of modern educational technology in sports teaching support is very weak, did not achieve the goal of front-line teachers expected.

The Ability to Apply Modern Educational Technology is Weak. In addition to the school's low attention and support to the application of modern educational technology in physical education, the weak ability of physical education teachers to use modern educational technology is also a prominent problem. 5 and 16 teachers were considered strong and strong, accounting for 6\% and $19 \%$ respectively. There are 23 teachers who have the ability to use modern educational technology, accounting for $27 \%$. Nearly $35 \%$ of the teachers surveyed thought they were weak in using modern educational technology, and 11 others thought they were weak in using modern educational technology. Modern educational technology needs effective use of physical education teachers. However, most of the physical education teachers in the application of modern educational technology is generally weak, restricting the effectiveness of physical education teaching.

Lack of Infrastructure. Of the 86 teachers, 14 were considered to have improved infrastructure, accounting for $16 \%$. There were 29 teachers who were considered to have basically improved infrastructure, accounting for no more than 35\%. It is considered that the modern educational technology infrastructure of sports is imperfect, with 43 people accounting for $50 \%$. From this result, most of the teachers interviewed have a low evaluation of the current situation of modern educational technology infrastructure construction in physical education. Due to the lack of necessary infrastructure, physical education teachers can not make good use of modern educational technology in teaching, which restricts the effect of modern educational technology in physical education.

\section{Thinking of development}

Strengthening Infrastructure Investment. In terms of input, universities are investing more in modern educational technology infrastructure. But devoted to sports modern educational technology investment is less. In view of this situation, the key is to do a good job in physical education. As an important support of modern educational technology, the network can no longer be separately withdrawn funds because of its sharing. From the results of the questionnaire, PE teachers generally reflect the lack of investment in the construction of specialized sports multimedia classroom in Colleges and universities. In view of this result, colleges and universities need to provide appropriate multimedia classrooms for physical education in terms of infrastructure investment.

Enhance the Ability of PE Teachers to Apply Modern Educational Technology. In terms of theoretical application, PE teachers should correct the traditional teaching concept of "teacher-centered", pay attention to the cultivation of students' interest and respect the students' principal position in teaching. At the same time, the role of teachers should be changed from "management" to "service". PE teachers are no longer the absolute administrators in teaching, but around all aspects of students 'learning, do a good job of guidance and guidance. In terms of operation technology, with the popularization of multimedia technology at present. PE teachers should strengthen the learning of office office software. In addition, we should master the basic technology of network operation to enhance the application ability of modern educational technology.

Play the Role of Students. It can give full play to the important role of students and let students participate in the experience and application of modern educational technology in teaching. In addition, PE teachers can also listen to students' opinions on the selection and application of specific modern educational technology. For teachers with poor computer skills and lack of modern educational skills, they can freely mobilize students to be fully responsible for the relevant courseware, teaching and even evaluation. By setting up open courses, not only enhance the liveliness of physical education teaching, but also respect the creativity of students. 


\section{Reference}

[1] He Ke Kang. Educational technology [M]. Beijing: Beijing Normal University press, 2016:14-16.

[2] Li Kedong. The new foundation of modern educational technology [M]. Shanghai: East China Normal University press,.2012:3.

[3] Guo Jinghua, Application of Modern Educational Technology in Higher Education in China [J].Journal of Gansu Union University, 2016 (5): 78-82.

[4] Xu Yan. On the Application of Modern Information Technology in College Teaching [J]. Communication Technology, 2014 (41): 280-281.

[5] Gu Ming Yuan. Educational technology and education in twenty-first Century [J]. Shaanxi audio-visual education, 2012 (2): 23. 